\title{
Real-Time Environmental Gamma Dose Rates Measurement and Evaluation of Annual Effective Dose to population of Shahbag Thana, Dhaka, Bangladesh
}

\section{${ }^{1}$ Shamsad Tazmin, ${ }^{2}$ Dr. Mohammad Sohelur Rahman, ${ }^{3}$ Selina Yeasmin, ${ }^{4}$ Dr. M. Habibul Ahsan, ${ }^{5}$ Md. Mahfuzzaman}

${ }^{1}$ MS Fellow, Department of Physics, Shahjalal University of Science and Technology, Sylhet-3114, Bangladesh

${ }^{2}$ Chief Scientific Officer, Health Physics Division, Atomic Energy Centre, 4 Kazi Nazrul Islam Avenue, Shahbag, Dhaka-1000, Bangladesh

${ }^{3}$ Chief Scientific Officer and Head, Health Physics Division, Atomic Energy Centre, 4 Kazi Nazrul Islam Avenue, Shahbag, Dhaka-1000, Bangladesh

${ }^{4}$ Professor, Department of Physics, Shahjalal University of Science and Technology, Sylhet-3114, Bangladesh ${ }^{5}$ MS Fellow, Department of Physics, Shahjalal University of Science and Technology, Sylhet-3114, Bangladesh

\begin{abstract}
:
Background: In this study, environmental gamma radiation dose rates were measured in the area of Shahbag Thana under Dhaka city, Bangladesh.

Aim of the study: This kind of study is required to detect the presence of natural and artificial radionuclides (if any) releasing from nuclear facilities in the country or from neighbouring countries. Materials and Method: The measurement was performed using a digital portable Gamma-Scout detector. The digital portable Gamma-Scout detector was placed at 1 meter above the ground on tripod and data acquisition time for each monitoring point (MP) was 1 hour. Total 27 MPs were selected for collection of gamma-ray dose rate in the outdoor environment of Shahbag Thana. The measurements were performed during light day from January to September 2017. The MPs were marked-out using Global Positioning System (GPS) navigation. The GP Sreading of the sampling locations were varied from E: $90^{\circ} 23^{\prime} 32.94^{\prime \prime}$ to E: $90^{\circ} 24^{\prime} 31.32^{\prime \prime}$ and from N:2344'19.38" to N: $23^{\circ} 43^{\prime} 24.3^{\prime \prime}$. Results: The measured dose rates due to natural radionuclides were ranged from $0.085 \pm 0.0245 \mu \mathrm{Sv} \cdot \mathrm{h}^{-1}$ to $0.190526 \pm 0.081886 \mu \mathrm{Sv} \cdot \mathrm{h}^{-1}$ with an average of $0.145265 \pm 0.025192 \mu \mathrm{Sv} \cdot \mathrm{h}^{-1}$. The annual effective dose to the population from outdoor environmental gamma radiation was varied from0.104244 $\pm 0.030041 \mathrm{mSv}$ to $0.233661085 \pm 0.100425 \mathrm{mSv}$. The range of dose rate and annual effective dosedue to outdoor environmental gamma radiation is lower than some countries like India, Sweden, China, CzechRepublic, Italy and higher than Canada, Turkey, Indonesia, Belgium, Albania, New Zealand and some other counties. Conclusion: From this study, it was observed that there is no burden of population exposure due to man-made sources. Therefore, it can be concluded that adequate safety and radiation protection of radiological facilities had been ensured which is required for minimizing of unnecessary exposure to populations from man-made sources. The estimated mean annual effective dose found in this study is not expected to contribute significant additional hazard from the radiological health point of view.
\end{abstract}

Key words: Environmental gamma radiation, effective dose, In-situ, Gamma-Scout detector.

\section{Introduction}

The exposure of human beings to ionizing radiation both from natural and man-made sources is a continuing and inescapable feature of life on earth [1] [2]. Environmental radioactivity measurements are necessary to determine the background radiation level due to natural radioactivity sources of terrestrial and cosmic origins [3]. Background radiation consists of three primary types: Primordial, cosmogenic and anthropogenic. 
Primordial radionuclides are present in the earth's crust and found throughout the environment. Cosmogenic radionuclides are produced when cosmic radiation interacts with elements present in the atmosphere and are deposited through both wet and dry deposition. Anthropogenic sources of radiation result from human activities, but are considered background because their presence is ubiquitous [4]. According to UNSCEAR, about $87 \%$ of the radiation dose received by mankind is from natural sources and the remaining is due to anthropogenic sources [5]. The main sources of the external gamma radiation are from the primordial radio nuclides like ${ }^{238} \mathrm{U}$, ${ }^{232} \mathrm{Th}$ and ${ }^{40} \mathrm{~K}$ that are present in the earth since its formation ${ }^{[6]}$, depending on the geological and geographical features of a region [3] [7] [9]. The primarily sources of cosmic radiation are the galaxies in outer space (galactic cosmic radiation) and secondarily source is the Sun in our solar system (significant during maximum sun cycle activity) ${ }^{[10]}$ whose contribution to background changes mainly with elevation and latitude [11] [12]. The galactic cosmic radiation coming at the upper atmosphere is made up of about $98 \%$ baryons and $2 \%$ electrons [10]. ${ }^{137} \mathrm{Cs},{ }^{134} \mathrm{Cs},{ }^{90} \mathrm{Sr}$ is an anthropogenic radionuclide might also contribute to human external exposure [13] [14]. The knowledge of the natural radioactivity of building materials is important for the determination of population exposure to radiations, as most of the residents spend about $80 \%$ of their time indoors and $20 \%$ of their outdoors [15]. In general, the health impact of exposure to radon $\left({ }^{222} \mathrm{Rn}\right)$ inhalation by humans in indoor environment is a major public concern worldwide. The exposure is due to the emanation of radon gas from the decay chains of radioactive thorium $\left({ }^{232} \mathrm{Th}\right)$ and uranium $\left({ }^{238} \mathrm{U}\right)$, which are present in soil layers and indoor construction materials especially granite ${ }^{[16]}$. The total amount of radioactivity in an environment should be accurately known and kept to a level as low as reasonably achievable (ALARA) [8].

Gamma ray accounts for the majority of external human exposures to radiation from all type of sources due to its high penetration ability [17]. Great variations have been observed in environmental radiation levels and several international studies have been characterized gamma dose rates both in outdoor and indoor environments [18] [25].

Both laboratory and in-situ gamma spectroscopy are often used for monitoring and assessment of radioactivity and radiation dose rates in the environment due to both natural and anthropogenic sources [26] [30]. In-situ techniques for measuring the activity concentration resulting from the gamma radiation and characterizing its sources with gamma ray spectrometer have been used successfully in outdoor and indoor environment [31] [33]. The assessment of the radiological impact on a population as a result of the radiation emitted by these radionuclides is important since they contribute to the collective dose of the population [34]. The aim of the present study is to measure outdoor environmental gamma-ray dose rates from natural and artificial radionuclides (if any) releasing from nuclear facilities in the country or from neighbouring countries in normal operation or in case of incident/accident through in-situ technique.

\section{Materials and Methods}

\subsection{In-Situ gamma-ray dose rate measurement}

The In-situ gamma-ray dose rate measurement is highly reliable in indoor and outdoor environments [35]. A real-time digital portable radiation monitoring device which is known as GAMMA SCOUT was used for this study. GAMMA SCOUT is German designed and manufactured, built with a solid Novadur exterior. An optional stylish leather holster with belt strap can further protect the GAMMA SCOUT from the elements. The GAMMA SCOUT meets all European CE standards as well as US FCC 15. All units come with an industry leading 2-year manufacturer's warranty and a serialized test certificate. The GAMMA SCOUT is a fully featured Geiger counter with a form fitting ergonomic shape. The unit has a battery indicator, multiple unit conversion, real-time dose rate and cumulative dose display functions and programmable logging and alert functions. Advanced functions include PC data download via USB cable and an ultra low current power circuit for extended battery life [36].

\subsection{Gamma-ray calibration sources}


The GAMMA SCOUT was calibrated inbuilt by the manufacturer. The GAMMA SCOUT is also calibrated at Secondary Standard Dosimetry Laboratory under Bangladesh Atomic Energy Commission using gamma-ray standard sources. The GAMMA SCOUT accurately measure dose rate in the range of 0.01-5000 $\mu \mathrm{Sv} / \mathrm{hr}$.

\subsection{The Site}

The study site is located from E: $90^{\circ} 23^{\prime} 32.94^{\prime \prime}$ to E: $90^{\circ} 24^{\prime} 31.32^{\prime \prime}$ and from N: $23^{\circ} 44^{\prime} 19.38^{\prime \prime}$ to N: $23^{\circ} 43^{\prime} 24.3^{\prime \prime}$. Twenty seven locations were selected to measure outdoor environmental gamma radiation dose rates in Shahbag Thana under Dhaka city. The measurements were performed during light day from January to September 2017. For each location, the real-time digital portable radiation monitoring device (GAMMA SCOUT) was placed on tripod at $1 \mathrm{~m}$ height and time for dose rate measurement was 1 hour. Figure 1 shows the location of area in Shahbag Thana under Dhaka city where outdoor environmental gamma radiation measurement was performed using portable Gamma-Scout detector through In-situ technique. Table 1 gives the description of monitoring points (MPs). This site was marked out using Global Positioning System (GPS) navigation. 


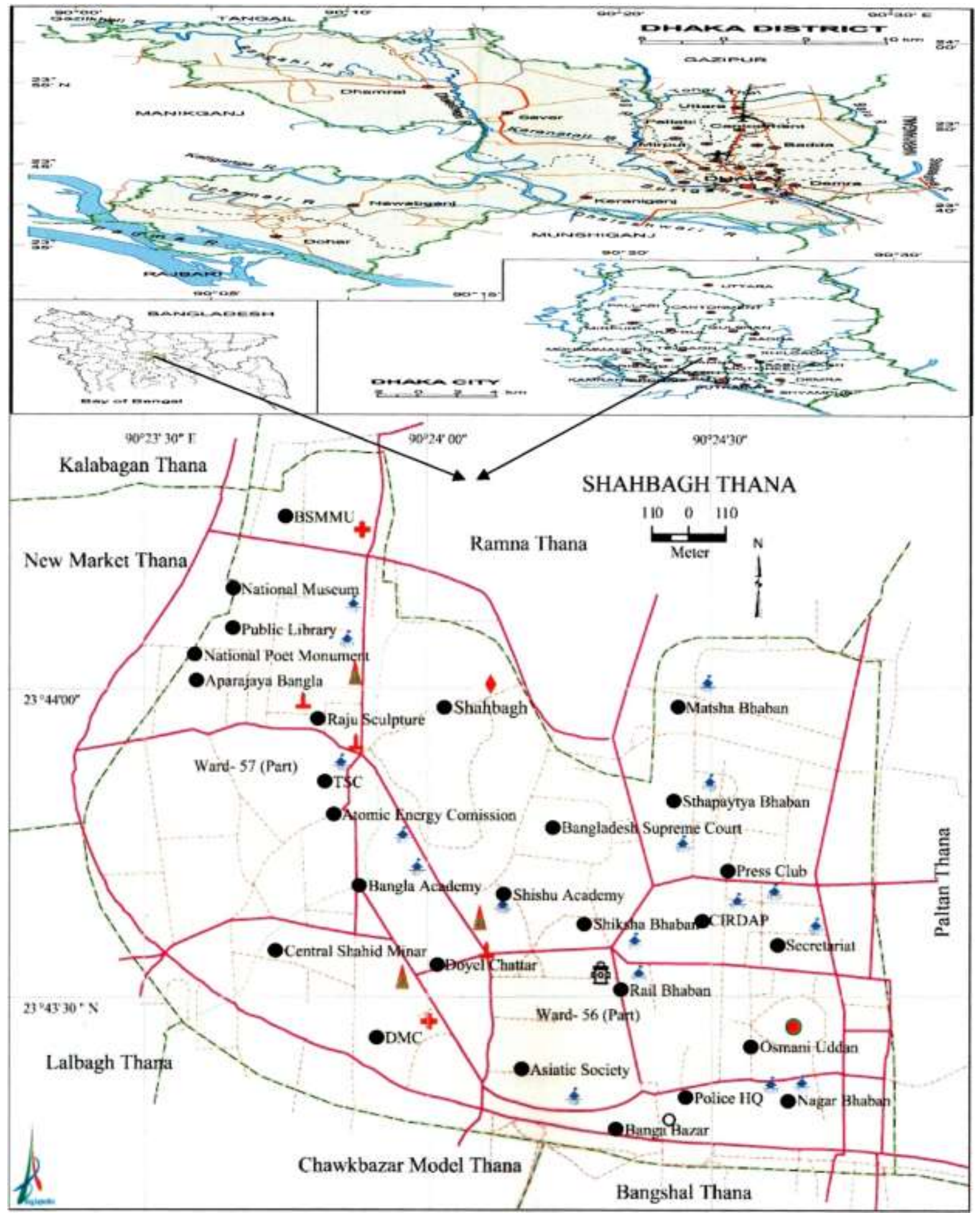

Figure 1: Shows the location $(\bullet)$ of Shahbag Thana under Dhaka city where outdoor environmental gamma radiation measurement was performed using portable Gamma-Scout detector through In-situ technique.

\section{Results and Discussion}

\subsection{Collection of field gamma-ray dose rate}

Measurement of outdoor environmental gamma radiation dose rate was carried out at the area of Shahbag Thana under Dhaka city from January-September 2017 following In-situ technique. The contribution of dose rates in all monitoring points arising from natural radionuclides. 


\subsection{Absorbed dose rate and annual effective dose}

The average outdoor environmental gamma radiation dose rate in the study area was found to be $0.145265 \pm$ $0.025192 \mu \mathrm{Sv}_{\mathrm{f}} \mathrm{h}^{-1}$. The measured dose rates were ranged from $0.085 \pm 0.024495 \mu \mathrm{Sv} \cdot \mathrm{h}^{-1}$ to $0.190526 \pm 0.081886$ $\mu \mathrm{Sv} \cdot \mathrm{h}^{-1}$ with an average of $0.145265 \pm 0.025192 \mu \mathrm{Sv}_{\mathrm{h}} \mathrm{h}^{-1}$. Using the conversion factor of $0.7 \mathrm{~Sv} \mathrm{~Gy}^{-1}$ as recommended by UNSCEAR $2000{ }^{[8]}$, and considering that people in Bangladesh spend approximately $20 \%$ of their time outdoor and remaining $80 \%$ of time indoor; the annual effective dose received by people in Dhaka city due to the environmental gamma radiation is given in Table 1.The annual effective dose rates of the population due to the outdoor environmental gamma radiation were also calculated and it was varied from $0.104244 \pm 0.030041 \mathrm{mSv}$ to $0.233661 \pm 0.100425 \mathrm{mSv}$. The mean annual effective dose was found to be $0.178153 \pm 0.030895 \mathrm{mSv}$.

Table 1: Outdoor dose rate and annual effective dose for 27 MPs at Shahbag Thana under Dhaka city.

\begin{tabular}{|c|c|c|c|c|c|}
\hline \multirow[t]{2}{*}{$\begin{array}{l}\text { Name of } \\
\text { Place }\end{array}$} & \multirow[t]{2}{*}{$\begin{array}{l}\text { Latitude/ } \\
\text { Altitude }\end{array}$} & \multicolumn{3}{|c|}{$\begin{array}{c}\text { Gamma dose rate } \\
(\mu \mathrm{Sv} / \mathrm{hr})\end{array}$} & \multirow{2}{*}{$\begin{array}{c}\text { Annual effective } \\
\text { dose due to gamma } \\
\text { radiation }(\mathrm{mSv}) \pm \\
\text { SD }\end{array}$} \\
\hline & & Range & Mean & SD & \\
\hline BSMMU & $\begin{array}{l}\mathrm{N} 23^{\circ} 44^{\prime} 19.3 \\
8^{\prime \prime} \\
\mathrm{E} 90^{\circ} 23^{\prime} 40.6 \\
2^{\prime \prime}\end{array}$ & $(0.06-0.18)$ & 0.12 & 0.038944 & $0.147168 \pm 0.047761$ \\
\hline Shahbag & $\begin{array}{l}\mathrm{N} 23^{\circ} 44^{\prime} 16.4 \\
4^{\prime \prime} \\
\mathrm{E} 90^{\circ} 23^{\prime} 45.6 \\
6 "\end{array}$ & $(0.07-0.15)$ & 0.11 & 0.027386 & $0.134904 \pm 0.033586$ \\
\hline $\begin{array}{l}\text { National } \\
\text { Museum }\end{array}$ & $\begin{array}{l}\mathrm{N} 23^{\circ} 44^{\prime} 15.1 \\
8^{\prime \prime} \\
\text { E90²3'43.6 } \\
8^{\prime \prime}\end{array}$ & $(0.02-0.24)$ & 0.156471 & 0.057981 & $0.191896 \pm 0.071108$ \\
\hline Public Library & $\begin{array}{l}\mathrm{N} 23^{\circ} 44^{\prime} 12.1 \\
2^{\prime \prime} \\
\mathrm{E} 90^{\circ} 23^{\prime} 39.7 \\
8^{\prime \prime}\end{array}$ & $(0.05-0.21)$ & 0.144615 & 0.048411 & $0.177356 \pm 0.059371$ \\
\hline $\begin{array}{l}\text { National Poet } \\
\text { Monument }\end{array}$ & $\begin{array}{l}\mathrm{N} 23^{\circ} 44^{\prime} 6.72 \\
" \\
\mathrm{E} 90^{\circ} 23^{\prime} 42.0 \\
6 "\end{array}$ & $(0.07-0.18)$ & 0.129 & 0.036652 & $0.158206 \pm 0.044949$ \\
\hline $\begin{array}{l}\text { Aparajaya } \\
\text { Bangla }\end{array}$ & $\begin{array}{l}\mathrm{N} 23^{\circ} 44^{\prime} 1.44 \\
" \\
\text { E90²3'32.9 } \\
4^{\prime \prime}\end{array}$ & $(0.05-0.32)$ & 0.186087 & 0.081058 & $0.228217 \pm 0.099409$ \\
\hline $\begin{array}{l}\text { Raju } \\
\text { Sculpture }\end{array}$ & $\begin{array}{l}\mathrm{N} 23^{\circ} 43^{\prime} 57.7 \\
8^{\prime \prime} \\
\mathrm{E} 90^{\circ} 23^{\prime} 43.1 \\
4^{\prime \prime}\end{array}$ & $(0.07-0.16)$ & 0.115 & 0.030277 & $0.141036 \pm 0.037131$ \\
\hline TSC & 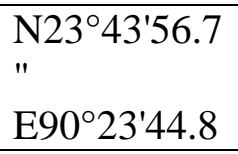 & $(0.09-0.21)$ & 0.15 & 0.038944 & $0.18396 \pm 0.047761$ \\
\hline
\end{tabular}




\begin{tabular}{|c|c|c|c|c|c|}
\hline & $8 "$ & & & & \\
\hline $\begin{array}{l}\text { Atomic } \\
\text { Energy } \\
\text { Commission }\end{array}$ & $\begin{array}{l}\mathrm{N} 23^{\circ} 43^{\prime} 50.6 \\
4 " \\
\text { E90²3'47.5 } \\
2^{\prime \prime}\end{array}$ & $(0.02-0.30)$ & 0.190526 & 0.081886 & $0.233661 \pm 0.100425$ \\
\hline $\begin{array}{l}\text { Bangla } \\
\text { Academy }\end{array}$ & $\begin{array}{l}\mathrm{N} 23^{\circ} 43^{\prime} 48.3 \\
6 " \\
\text { E90²3'52.2 } \\
6 "\end{array}$ & $(0.08-0.23)$ & 0.152667 & 0.048324 & $0.18723 \pm 0.058388$ \\
\hline Doyel Chattar & $\begin{array}{l}\mathrm{N} 23^{\circ} 43^{\prime} 40.6 \\
2^{\prime \prime} \\
\mathrm{E} 90^{\circ} 24^{\prime} 2.28 \\
"\end{array}$ & $(0.05-0.17)$ & 0.11 & 0.038944 & $0.134904 \pm 0.047761$ \\
\hline $\begin{array}{l}\text { Shishu } \\
\text { Academy }\end{array}$ & $\begin{array}{l}\mathrm{N} 23^{\circ} 43^{\prime} 41.8 \\
2^{\prime \prime} \\
\mathrm{E} 90^{\circ} 24^{\prime} 4.2^{\prime \prime}\end{array}$ & $(0.07-0.19)$ & 0.121538 & 0.053048 & $0.149055 \pm 0.047761$ \\
\hline $\begin{array}{l}\text { Bangladesh } \\
\text { Supreme } \\
\text { Court }\end{array}$ & $\begin{array}{l}\mathrm{N} 23^{\circ} 43^{\prime} 42.2 \\
4 " \\
\text { E90 } \\
"\end{array}$ & $(0.08-0.23)$ & 0.155 & 0.04761 & $0.190092 \pm 0.058388$ \\
\hline $\begin{array}{l}\text { Sikhsha } \\
\text { Bhaban }\end{array}$ & $\begin{array}{l}\mathrm{N} 23^{\circ} 43^{\prime} 41.7 \\
" \\
\mathrm{E} 90^{\circ} 24^{\prime} 15.5 \\
4^{\prime \prime} \\
\end{array}$ & $(0.07-0.19)$ & 0.138182 & 0.036556 & $0.169466 \pm 0.044833$ \\
\hline CIRDAP & $\begin{array}{l}\mathrm{N} 23^{\circ} 43^{\prime} 45.1 \\
2^{\prime \prime} \\
\text { E90²4'18.8 } \\
4^{\prime \prime}\end{array}$ & $(0.11-0.22)$ & 0.165 & 0.036056 & $0.202356 \pm 0.044218$ \\
\hline Secretariat & $\begin{array}{l}\mathrm{N} 23^{\circ} 43^{\prime} 40.6 \\
8^{\prime \prime} \\
\text { E90²4'31.3 } \\
2^{\prime \prime} \\
\end{array}$ & $(0.05-0.23)$ & 0.150625 & 0.054341 & $0.184727 \pm 0.066643$ \\
\hline Press Club & $\begin{array}{l}\mathrm{N} 23^{\circ} 43^{\prime} 46.8 \\
6 " \\
\text { E90²4'25.8 } \\
6 " \\
\end{array}$ & $(0.09-0.22)$ & 0.145 & 0.04378 & $0.177828 \pm 0.053691$ \\
\hline Rail Bhaban & $\begin{array}{l}\mathrm{N} 23^{\circ} 43^{\prime} 39.3 \\
6^{\prime \prime} \\
\text { E90²4'21.0 } \\
6 "\end{array}$ & $(0.08-0.22)$ & 0.145714 & 0.043095 & $0.178704 \pm 0.052851$ \\
\hline $\begin{array}{l}\text { Osmani } \\
\text { Uddan }\end{array}$ & $\begin{array}{l}\mathrm{N} 23^{\circ} 43^{\prime} 34.3 \\
8^{\prime \prime} \\
\text { E90²4'30.8 } \\
4^{\prime \prime}\end{array}$ & $(0.07-0.20)$ & 0.135 & 0.041833 & $0.165564 \pm 0.051304$ \\
\hline Police HQ & $\begin{array}{l}\mathrm{N} 23^{\circ} 43^{\prime 29.1} \\
" \\
\mathrm{E} 90^{\circ} 24^{\prime} 26.6 \\
4^{\prime \prime}\end{array}$ & $(0.12-0.25)$ & 0.183077 & 0.042892 & $0.224526 \pm 0.051304$ \\
\hline Nagar Bhaban & $\begin{array}{l}\text { N234'ㄹ․ } \\
"\end{array}$ & $(0.07-0.20)$ & 0.135 & 0.041833 & $0.165564 \pm 0.051304$ \\
\hline
\end{tabular}




\begin{tabular}{|c|c|c|c|c|c|}
\hline & $\begin{array}{l}\text { E90²4'29.4 } \\
\text { " }\end{array}$ & & & & \\
\hline $\begin{array}{l}\text { Matsha } \\
\text { Bhaban }\end{array}$ & $\begin{array}{l}\mathrm{N} 23^{\circ} 44^{\prime} 1.32 \\
" \\
\mathrm{E} 90^{\circ} 24^{\prime} 14.5 \\
2^{\prime \prime}\end{array}$ & $(0.09-0.23)$ & 0.164286 & 0.043095 & $0.20148 \pm 0.052851$ \\
\hline $\begin{array}{l}\text { Sthapaytya } \\
\text { Bhaban }\end{array}$ & $\begin{array}{l}\mathrm{N} 23^{\circ} 43^{\prime} 58.8 \\
" \\
\text { E90²4'17.4 } \\
"\end{array}$ & $(0.07-0.20)$ & 0.135 & 0.041833 & $0.165564 \pm 0.051304$ \\
\hline $\begin{array}{l}\text { Central } \\
\text { Shaheed } \\
\text { Minar }\end{array}$ & $\begin{array}{l}\mathrm{N} 23^{\circ} 43^{\prime} 39.3 \\
6 " \\
6^{\prime \prime} 90^{\circ} 23^{\prime} 46.0 \\
2^{\prime \prime}\end{array}$ & $(0.10-0.22)$ & 0.16 & 0.038944 & $0.196224 \pm 0.047761$ \\
\hline DMC & $\begin{array}{l}\mathrm{N} 23^{\circ} 43^{\prime} 35.0 \\
4^{\prime \prime} \\
\text { E90²3'49.8 } \\
"\end{array}$ & $(0.11-0.23)$ & 0.17 & 0.038944 & $0.208488 \pm 0.047761$ \\
\hline $\begin{array}{l}\text { Asiatic } \\
\text { Society }\end{array}$ & $\begin{array}{l}\mathrm{N} 23^{\circ} 43^{\prime} 27.4 \\
2^{\prime \prime} \\
\text { E90 } 24^{\prime} 8.88 \\
"\end{array}$ & $(0.09-0.26)$ & 0.169375 & 0.052974 & $0.207722 \pm 0.064967$ \\
\hline Banga Bazar & $\begin{array}{l}\mathrm{N} 23^{\circ} 43^{\prime} 24.3 \\
" \\
\mathrm{E} 90^{\circ} 24^{\prime} 19.3 \\
2^{\prime \prime}\end{array}$ & $(0.05-0.12)$ & 0.085 & 0.024495 & $0.104244 \pm 0.030041$ \\
\hline
\end{tabular}

From Table 1 we can see that the highest dose rate was observed in Atomic Energy Centre, Dhaka (AECD) and the lowest in Banga Bazar with respective values of $0.190526 \pm 0.081886 \mu \mathrm{Sv} / \mathrm{h}$ and $0.085 \pm 0.024495 \mu \mathrm{Sv} / \mathrm{h}$. The highest dose rate at AECD is observed because high activity industrial radiography source was placed in AECD campus. It is also indicated that there is a direct relationship between background dose rate and latitude of the region. Banga Bazar, located in south eastern part of Shahbag thana, has lower background gamma radiation in comparison to higher latitude regions of Shahbag thana. One main reason for this phenomenon is magnetic field of the earth which increases by latitude and reach to the optimum value at poles. Magnetic field of the earth can affect slow moving charged particles and diverts them towards the poles [37] [38].

The annual effective dose range due to the outdoor environmental gamma radiation to the population of Dhaka city is tabulated in Table 2. It can be seen from Table 2 that the range of dose rate and annual effective dose to population of Shahbag is lower than some countries like India, Sweden, China, Czech Republic, Italy and higher than Canada, Turkey, Indonesia, Belgium, Albania, New Zealand and some other counties. The exact reason for high radiation doses are not known, but might be attributed to geographical, geological, and altitude of cities studied. 


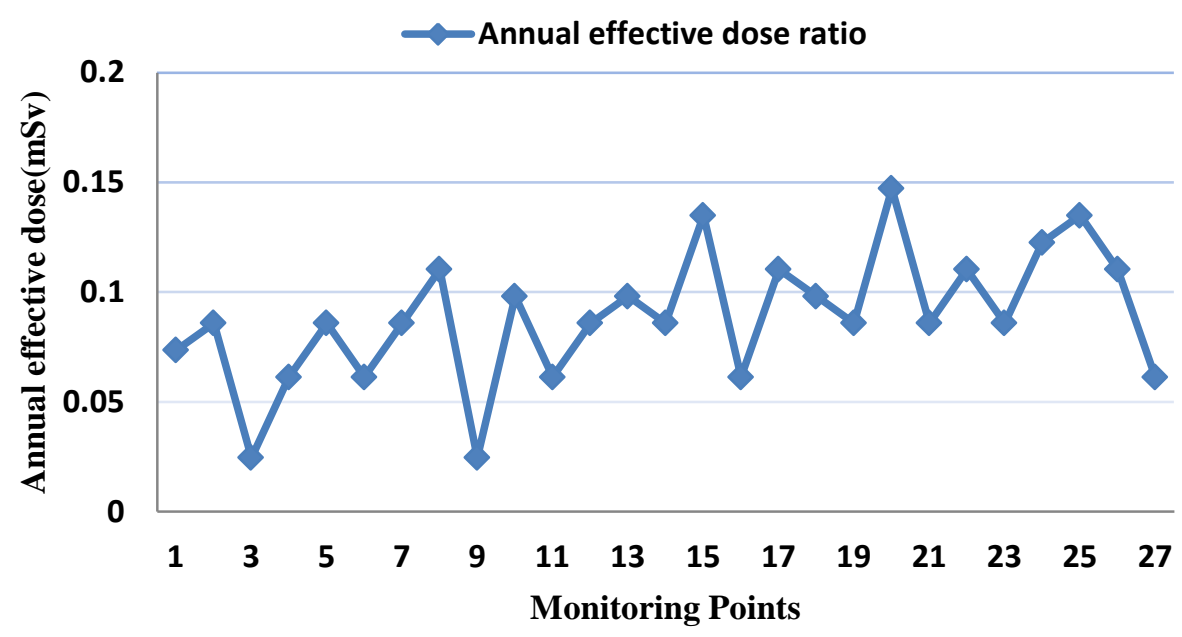

Figure 2: Outdoor annual effective dose values normalized to the minimum annual effective dose for each MPs.

The frequency distribution of the environmental gamma dose rates follow a normal type distribution as shown in Figure 3.

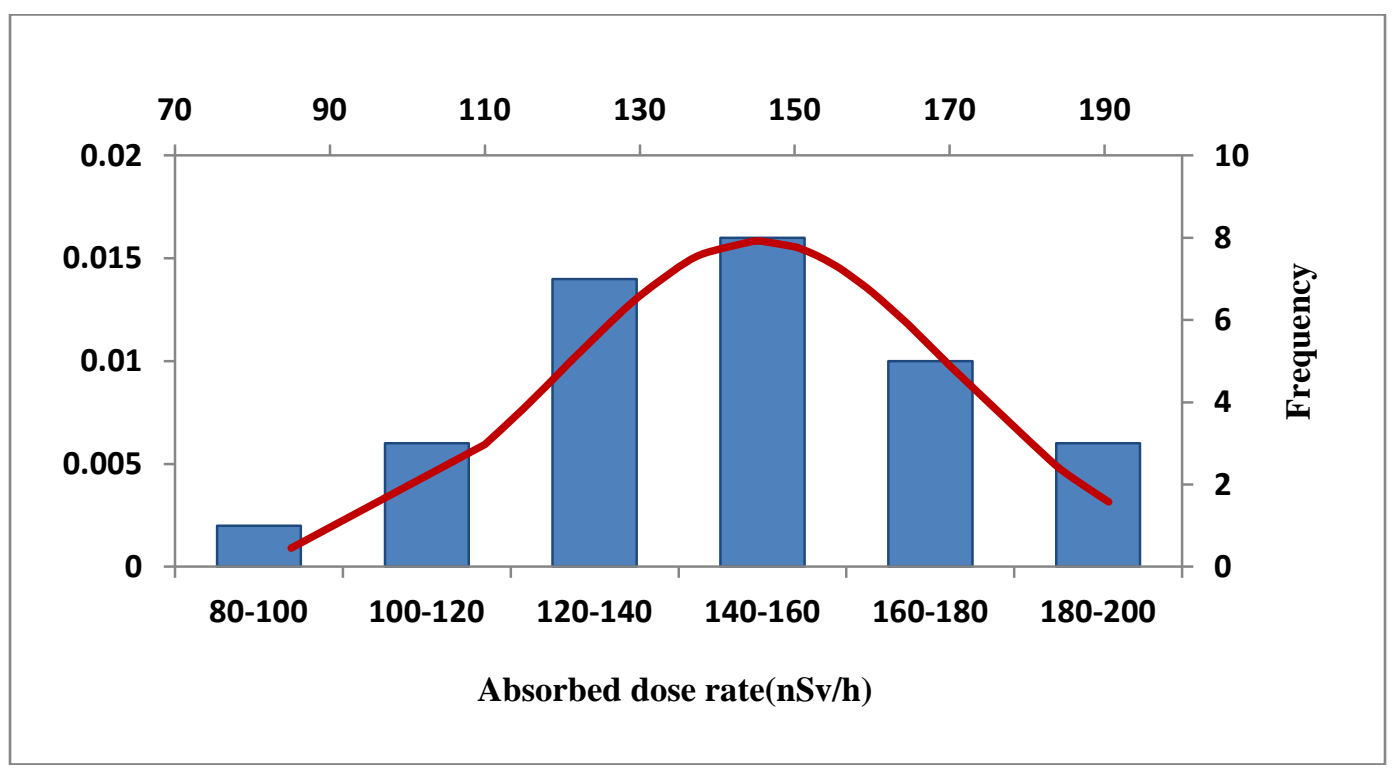

Figure 3: Frequency distribution of the dose rates $\left(\mathrm{nSv} \cdot \mathrm{h}^{-1}\right)$ at area of Shahbag Thana under Dhaka city follow normal distribution.

Table 2: Environmental gamma dose rate range and annual effective dose range due to natural radionuclide sources for selected countries and for this study [UNSCEAR 2008] ${ }^{[39]}$

\begin{tabular}{|c|c|c|c|}
\hline Country & $\begin{array}{l}\text { Range of Dose } \\
\text { rate }\left(\mu \mathrm{Sv} \cdot \mathbf{h}^{-1}\right)\end{array}$ & $\begin{array}{c}\text { Mean Gamma } \\
\text { Dose rate } \\
\left(\boldsymbol{\mu S v} \cdot \mathbf{h}^{-1}\right)\end{array}$ & $\begin{array}{c}\text { Range of annual } \\
\text { effective dose } \\
(\mathrm{mSv})\end{array}$ \\
\hline $\begin{array}{l}\text { Libyan Arab } \\
\text { Jamahiriya }\end{array}$ & $0.048-0.054$ & 0.051 & $0.059-0.066$ \\
\hline Mauritius & $0.08-0.126$ & 0.098 & $0.098-0.155$ \\
\hline Tanzania & $0.098-0.121$ & 0.104 & $0.120-0.148$ \\
\hline
\end{tabular}




\begin{tabular}{|c|c|c|c|}
\hline (United Rep. of) & & & \\
\hline Canada & $0.031-0.075$ & 0.054 & $0.038-0.092$ \\
\hline Mexico & $0.023-0.184$ & 0.088 & $0.028-0.226$ \\
\hline Costa Rica & $0.035-0.147$ & 0.066 & $0.043-0.180$ \\
\hline Odisha, India & $0.251-0.879$ & 0.449 & $0.308-1.078$ \\
\hline Cuba & $0.038-0.196$ & 0.055 & $0.047-0.240$ \\
\hline Azerbaijan & $0.075-0.205$ & 0.140 & $0.092-0.251$ \\
\hline China & $0.011-0.523$ & 0.815 & $0.013-0.641$ \\
\hline Indonesia & $0.045-0.102$ & 0.0675 & $0.055-0.125$ \\
\hline Korea & $0.018-0.200$ & 0.079 & $0.022-0.245$ \\
\hline Turkey & $0.032-0.094$ & 0.065 & $0.039-0.115$ \\
\hline Denmark & $0.056-0.101$ & 0.066 & $0.069-0.124$ \\
\hline Finland & $0.077-0.171$ & 0.103 & $0.094-0.209$ \\
\hline Lithuania & $0.079-0.115$ & 0.095 & $0.097-0.141$ \\
\hline Sweden & $0.040-0.630$ & 0.097 & $0.049-0.773$ \\
\hline Belgium & $0.045-0.102$ & 0.076 & $0.055-0.125$ \\
\hline Ireland & $0.035-0.143$ & 0.065 & $0.043-0.175$ \\
\hline Italy & $0.057-0.243$ & 0.112 & $0.069-0.298$ \\
\hline Spain & $0.050-0.129$ & 0.085 & $0.061-0.158$ \\
\hline Switzerland & $0.053-0.155$ & 0.081 & $0.065-0.190$ \\
\hline Bulgaria & $0.075-0.140$ & 0.100 & $0.092-0.172$ \\
\hline Czech Republic & $0.040-0.285$ & 0.100 & $0.049-0.349$ \\
\hline Poland & $0.051-0.126$ & 0.080 & $0.063-0.155$ \\
\hline Romania & $0.052-0.163$ & 0.092 & $0.065-0.199$ \\
\hline Albania & $0.077-0.103$ & 0.094 & $0.094-0.126$ \\
\hline Croatia & $0.070-0.140$ & 0.115 & $0.086-0.172$ \\
\hline New Zealand & $0.034-0.122$ & 0.076 & $0.042-0.149$ \\
\hline This Study & 0.085 - 0.191 & 0.145 & $0.104-0.234$ \\
\hline
\end{tabular}

United Nations Scientific Committee on the Effects of Atomic Radiation (UNSCEAR) estimated global dose rate in outdoor due to natural background radiation to be on average $59 \mathrm{nGy} / \mathrm{h}$ and population weighed average of effective environmental gamma dose rate is $0.072 \mathrm{mGy} / \mathrm{y}$ [8]. Assuming this dose rate as a normal level, doses quantified in my study area are approximately 1.45 to 3.25 times higher than worldwide population weighted average and that people living in this area receive on average approximately 2.5 times higher environmental gamma radiation than the world population weighted average.

The estimated mean annual effective dose of $0.178 \mathrm{mSv}$ is not expected to contribute significant additional hazard from the radiological health point of view. Due to comparison purposes, the annual dose limit for members of the public according to ICRP 103 (2007 recommendation) [40] is $1 \mathrm{mSv} / \mathrm{year}$, and this limit is applicable to practices giving rise to controllable exposure and is not applicable to doses received from natural sources.

\section{Conclusion}

The present study has measured the outdoor environmental gamma radiation dose rates in the area of Shahbag Thana under Dhaka city. The average outdoor environmental gamma radiation dose rate in the study area was found to be $0.145265 \pm 0.025192 \mu \mathrm{Sv} \cdot \mathrm{h}^{-1}$ which is higher than the world average value. The measured dose rates were ranged from $0.085 \pm 0.024495 \mu \mathrm{Sv} \cdot \mathrm{h}^{-1}$ to $0.190526 \pm 0.081886 \mu \mathrm{Sv} \cdot \mathrm{h}^{-1}$ with an average of $0.145265 \pm$ $0.025192 \mu \mathrm{Sv} \cdot \mathrm{h}^{-1}$. The annual effective dose rates of the population due to the outdoor environmental gamma radiation were varied from $0.104244 \pm 0.030041 \mathrm{mSv}$ to $0.233661 \pm 0.100425 \mathrm{mSv}$. The mean annual effective 
dose was found to be $0.178153 \pm 0.030895 \mathrm{mSv}$. This type of study is very important for our country because the usage of radioactive material is increasing day by day in the various fields like medicine, industry and research \& education. Moreover, environmental radiation and radioactivity monitoring is crucial to generate the baseline data from natural sources. This kind of study is required to detect the presence of natural radionuclides and artificial radionuclides (if any) releasing from nuclear installations in the country or from neighboring countries in normal operations or in case of accident/incident. From this study, it can be concluded that the assessment of the radionuclide level of the area did not detect the presence of any artificial radionuclides and thus no significant impact of the extensive usage of radioactive materials within and around the area of Shahbag Thana and no radiation burden of the environment. This kind of study will also be needed for measurement of environmental radioactivity in and around the Rooppur Nuclear Power Project (RNPP) site area in Pabna of Bangladesh for generation of baseline database. From this study, it can be concluded that the assessment of the dose level of the area did not detect the presence of any artificial radionuclides and thus no significant impact of the extensive usage of radioactive materials in and around Shahbag Thana and no radiation burden to the environment. Finally, it can be concluded that adequate safety and radiation protection of nuclear \& radiological facilities had been ensured which is required for minimizing of unnecessary exposure to populations from manmade sources.

\section{Acknowledgement}

The authors would like to thank concerned personnel of Health Physics Division, Atomic Energy Center, Dhaka for their support.

\section{References}

[1] Ononugbo, C.P., Mgbemere, C.J , "Dose Rate and Annual Effective Dose Assessment of Terrestrial Gamma Radiation in Notre Fertilizer Plant, Onne, Rivers State, Nigeria", International Journal of Emerging Research in Management \&Technology ISSN: 2278-9359 (Volume-5, Issue-9), September 2016

[2] Monica S, Visnu Prasad AK, Soniya SR, Jojo PJ, "Estimation of indoor and outdoor effective doses and lifetime cancer risk from gamma dose rates along the coastal regions of Kollam district, Kerala", Radiat Prot Environ, vol 39, pp38-43, 2016.

[3] M. Gholami, S. Mirzaei, A. Jomehzadeh, "Gamma background radiation measurement in Lorestan province, Iran", Iran. J. Radiat. Res., Vol 9(2), pp 8993, 2011

[4] Okeyode I. C and Oluseye A. M, "Studies of the Terrestrial outdoor Gamma Dose Rate Levels in OgunOsun River Basins Development Authority Headquarters, Abeokuta, Nigeria", Phy. Intl. 1 (1): 1-8, 2010.

[5] UNSCEAR, Sources and effects of ionizing radiation. United Nations Scientific Committee on the Effect of Atomic Radiation, Report to the General Assembly with Scientific Annexes, New York, 1993.

[6] Olarinoye, I.O., Sharifat, I., Baba-Kutigi, A, N., Kolo, M.T., Aladeniyi, K., "Measurement of Background Gamma Radiation Levels at Two Tertiary Institutions in Minna, Nigeria", J. Appl. Sci. Environ. Manage, Vol. 14(1) 59 - 62, March, 2010.

[7] Essiett A. A., Essien I. E., Bede M. C. , "Measurement of Surface Dose Rate of Nuclear Radiation in Coastal Areas of Akwa Ibom State, Nigeria ", International Journal of Physics, Vol. 3, No. 5, 224-229, 2015.

[8] UNSCEAR. Source and Effects of Ionizing Radiation. Report to General Assembly, with Scientific Annexes. United Nations Scientific Committee on the Effects of Atomic Radiation, United Nations, New York, pp 265-273, 2000.

[9] UNSCEAR. Source and Effects of Ionizing Radiation. Report to General Assembly, with Scientific Annexes. United Nations Scientific Committee on the Effects of Atomic Radiation, United Nations, New York, pp. 19-220, 2010.

[10] Reitz G., 1993. Radiation Environment in the Stratosphere. Health Physics 48, 5. 
[11] Erol Kam and Ahmet Bozkurt, "Environmental radioactivity measurements in Kastamonu region of northern Turkey", Applied Radiation and Isotops, Vol 65, pp 440-444, (2007).

[12] Ahmet Bozkurt, Nuri Yorulmaz, Erol Kam, "Assessment of environmental radioactivity for Sanliurfa region of southeastern Turkey", Radiation Measurement, 42: 1387-1391, (2007).

[13] E. B. Faweya, M. J. Ayeni, J. Kayode, "Accumulation of Natural Radionuclides by Some Edible Wild Mushrooms in Ekiti State, Southwestern, Nigeria" World Journal of Nuclear Science and Technology, 2015, 5, 107-110

[14] Hu, Q.H., Weng, J.Q. and Wang, J.S., "Sources of Anthropogenic Radionuclides in the Environment: A Review", Journal of Environmental Radioactivity, 101, 426-437, 2010.

[15] Stoulos, S., Manolopoulou, M., Papastefanou, C, "Assessment of natural radiation exposure and radon exhalation from building materials in Greece", J. Environ. Radioactivity. 69, 225-240, 2003.

[16] Kobeissi MA, Omar ES, Khaled Z, Ibrahim R. "Assessment of Indoor and Outdoor Radon Levels in South Lebanon", New York: Springer; 2014. p. 214-26.

[17] Al-Saleh FS, "Measurements of indoor gamma radiation and radon concentrations in dwellings of Riyadh city, Saudi Arabia", Appl Radiat Isot,65, pp. 843-848,2007.

[18] F.H. Al-Ghorable, "Measurement of environmental terrestrial gamma radiation dose rate in three mountainous locations in the western region of Saudi Arabia", Environ Res, 98, pp. 160-166, 2005.

[19] H. Arvela, "Population distribution of doses from natural radiation in Finland", Int Congr Ser, 1225, pp. 9-14, 2002.

[20] L. Rybach, D. Bachler, B. Bucher, G. Schwarz, "Radiation doses of Swiss population from external sources", J Environ Radiat, 62, pp. 277-286, 2002.

[21] F. Sagnatchi, M. Salouti, A. Eslami, "Assessment of annual effective dose due to natural gamma radiation in Zanjan (Iran)", Radiat Prot Dosim., 132, pp. 346-349, 2008.

[22] M.B. Tavakoli, "Annual background radiation in the city of Isfahan", Med Sci Monit, 9, pp. 7-10, 2003.

[23] E. Svoukis, H. Tsertos, "Indoor and outdoor In situ high-resolution gamma radiation measurements in urban area of Cyprus", Radiat Prot Dosim., 123(3), pp. 384-390, 2007.

[24] R. Rangaswamy, E. Srinivasa, M.C. Srilatha, Jadiyappa Sannappa, "Measurement of terrestrial gamma radiation dose and evaluation of annual effective dose in Shimoga District of Karnataka State, India", Radiation Protection and Environment, Vol. 38, Issue 4, pp.154-159, 2005.

[25] Allawi Hamed Alasadi, Azhar S. Alaboodi, Lubna A. Alasadi, Ali Abid Abojassim, "Survey of absorbed dose rates in air of Buildings Agriculture and Sciences in University of Kufa at Al-Najaf Governorate, Iraq", Journal of Chemical and Pharmaceutical Research, 8(4), pp.1388-1392, 2016.

[26] Nikl, L. B. Sztanyik, "External indoor and outdoor gamma exposures in Hungary during the period of 1983-86", Radiat. Prot. Dosim., 24 (1/4), pp. 387-389, 1988.

[27] International Commission on Radiation Units and Measurements, ICRU Report 53, -Gamma-ray spectrometry in the environment, 1994. Othman, and T. Yassine, -Natural radioactivity in the Syrian environment,\|Sci. of Tot. Environ, 170, pp.119-124, 1995.

[28] M. Tzortzis, H. Tsertos, S. Christofides and G. Christodoulides, "Gamma-ray measurements of naturally occurring radioactive samples from Cyprus characteristic geological rocks", Radiat.Measur, 37, pp. 221229, 2003.

[29] X. S. Clouvas and M. Antonopoulos-Domis, "Radiological Maps of indoor and outdoor gamma dose rates in Greek Urban areas obtained by in-situ gamma spectrometry", Radiat. Prot. Dosim., 112 (2), 267275, 2004.

[30] B. Petalas, E. Vogiannis, D. Nikolopoulos, and C. P. Halvadakis, "Preliminary survey of outdoor gamma dose rates in Lesvos Island (Greece)", Radiat. Prot. Dosim., 113 (3), pp. 336-341, 2005.

[31] Radiation and Risk: Expert Perspectives. Health Physics Society; 2017.

[32] N. Karunakara, I. Yashodhara, K. Sudeep Kumara, R.M. Tripathi, S.N. Menon, S. Kadam and M.P. Chougaonkar, "Assessment of ambient gamma dose rate around a prospective uranium mining area of South India-A comparative study of dose by direct methods and soil radioactivity measurements", Results in Physics 4, pp. 20-27, 2014. 
[33] S. Selvasekarapandian, K.S. Lakshmi, G.M. Brahmanandhan, V. Meenakshisundaram, "Indoor gamma dose measurement along the east coast of Tamilnadu, India using TLD", Int Congr Ser, 1276, pp. 327328, 2005.

[34] United Nation Scientific Committee on the Effects of Atomic Radiation, - Sources and Biological Effects of Ionizing Radiation,\| (Report to the General Assembly) New York, United Nations, 2008.

[35] Clouvas, A., Xanthos, S. and Antonopoulos - Domis, M. "Extended survey of indoor and outdoor gamma radiation in Greek urban areas by in situ gamma spectrometry with a portable Ge detector", Radiation Protection Dosimetry 94, 233-246 (2001)

[36] https://www.gammascout.com/\#

[37] Bahreyni Toossi MT, Bayani S, Yarahmadi M, Aghamir A, Jomehzadeh A, Parast MH, Tamjidi A. Gonad, "Bone marrow and effective dose to the population of more than 90 towns and cities of Iran, arising from environmental gamma radiation", Iran J Radiat Res., Vol 7, pp 41-47, 2009.

[38] Bouzarjomehri F, Ehrampoush M., "Gamma background radiation in Yazd province; a preliminary report", Iran J Rad Res., Vol 3, pp 17-20, 2005.

[39] UNSCEAR. REPORT Vol. I -Sources and effects of ionizing radiation, Annex B: Exposures of the public and workers from various sources of radiation, New York: United Nations Scientific Committee on the effects of atomic radiation; 2008.

[40] ICRP 2007. The 2007 Recommendation of the International Commission on Radiological Protection. ICRP Publication 103. Ann. ICRP 37(2-4), 2007. 